Winter 2013

\title{
Visible Formalizations and Formally Invisible Facticities
}

\author{
Saskia Sassen \\ Columbia University, sjs2@columbia.edu
}

Follow this and additional works at: https://www.repository.law.indiana.edu/ijgls

Part of the International Law Commons

\section{Recommended Citation}

Sassen, Saskia (2013) "Visible Formalizations and Formally Invisible Facticities," Indiana Journal of Global Legal Studies: Vol. 20 : Iss. 1 , Article 2.

Available at: https://www.repository.law.indiana.edu/ijgls/vol20/iss1/2

This Symposium is brought to you for free and open access by the Law School Journals at Digital Repository @ Maurer Law. It has been accepted for inclusion in Indiana Journal of Global Legal Studies by an authorized editor of Digital Repository @ Maurer Law. For more information, please contact rvaughan@indiana.edu.

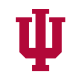

JEROME HALL LAW LIBRARY INDIANA UNIVERSITY Maurer School of Law
Bloomington 


\title{
Visible Formalizations and Formally Invisible Facticities
}

\author{
SASKIA SASSEN
}

\begin{abstract}
This essay focuses on a range of formal and informal practices that I hypothesize as the making of new types of jurisdictions with variable relations to the traditional jurisdiction of the state over its territory. One effect is to contribute to an emergent misalignment between territory and territoriality. A second effect is to make structural holes in the tissue of national state sovereign territory. Both processes contribute new types of borderings inside national territory. The action is not on interstate borders, but in the interior of the state, which can mean an extension of one state into another's territorial jurisdiction or into the high seas, a zone where no state has exclusive jurisdiction. I also explore whether these formations are hidden from the formal eye of the state by the contractualizing of governmental authority.
\end{abstract}

\section{INTRODUCTION}

There is much that can be rendered invisible in complex systems, intentionally or unintentionally. The instruments, intentions, and accidental outcomes leading to or generating this invisibility vary enormously across different epochs and their particular formalized systems. Further, what may remain invisible, even though present and consequential, in one type of formalized system, can be highly present in another but be less significant. In this essay I will explore such interactions between visible formalizations and invisible facticities; I use the concept of facticities to capture conditions that have the

* Saskia Sassen is the Robert S. Lynd Professor of Sociology and Co-Chair, The Committee on Global Thought, Columbia University (www.saskiasassen.com). Her recent books include: TERRITORY, AUTHORITY, RIGHTS: FROM MEDIEVAL TO GLOBAL ASSEMBLAGES (2008) and Digital Formations: IT AND NEW ARCHITECTURES IN THE GLOBAL REALM (2005) (both from Princeton University Press). She is currently completing UNGOVERNED TERRITORIES (Harvard University Press). Her books are translated into over twenty languages and she is the recipient of multiple honors.

Indiana Journal of Global Legal Studies Vol, 20, Issue 1 (2013)

(C) Indiana University Maurer School of Law 
properties of facts but may not quite be facts because they belong to complex systems not easily reduced to the empirical. ${ }^{1}$ I engage these questions by focusing on one particular formalized system, the state's sovereign authority over its national territory.

Partly due to globalization and its destabilizing of national borders, we can now detect particular formations that may long have been there in less developed condition or merely incipient-some inherited from earlier epochs, and some new. Formally, they are not legible through national state law. At least in some cases, they are unrecognized but functioning operational spaces. We can conceive of these formations as an ironic version of the terra nullius of an older era, when what could not be mapped because it was unknown was represented as a terra nullius. ${ }^{2}$ In a way, we are now entering a post-mapped era, one that has gone beyond the interstate system as formally mapped. Even if today, as in the past, this system is continuously being mapped, I argue that this is more an aspiration to precise mapping. In contrast, the mapping project of centuries past was all encompassing-early explorers "discovering" the world and emergent states fighting for ownership both of meters of terrain and vast overseas colonies.

\section{EMERGENT INFORMAL JURISDICTIONS}

The current "mapped" era helps make visible the emergence of new spaces, so new that they are still a kind of terra nullius in the formal interstate system. These new spaces arise partly due to the incipient, often partial but punctual, disassembling of that older interstate system with its unitary formations, the nation-states of the twentieth century. This process cannot be confined to a remapping of interstate borders. It entails an internal disassembling of nation-states, and is less visible to the eye of the law than would a change to an interstate border.

Diverse facticities are making these emergent disassemblings visible. Some of these are new; others are old, but long invisible to the interstate system. For instance, recognition of the need to protect the habitats of fisheries has generated new types of emergent jurisdictions

1. Saskia Sassen, Territory, Authority, Rights: From Medieval to Global ASSEMBLAGES 378-423 (2d ed. 2008).

2. Terra Nullius is a term derived from Roman Law that is used in international law to describe territory that does not fall under any sovereign authority, or is not claimed by any sovereign. See Tim Rowse, Terra Nullius, in THE OXFord COMPANION TO AUSTRALIAN HISTORY 643 (Graeme Davison, John Hirst \& Stuart Macintyre eds., 2001). The U.S. Supreme Court has had cases where this term is used. See, e.g., State of New Jersey v. State of New York, 523 U.S. 767, 788 (1922). 
that can be in conflict with older jurisdictions. ${ }^{3}$ Thus, when such a habitat cuts across interstate borders, it can lead to considerable legal debates if, for instance, there is an international law that protects fisheries, and either overrides or enters in competition with older interstate law. The long-term fisheries dispute between the United States and Canada would then acquire a new element, a sort of third party's interest-the protection of the natural habitat of fisheries that cut across national borders. ${ }^{4}$ A very different and highly instrumental case is the use of the "high seas" as an operational space to stop refugee entries and avoid non-refoulement rules; this has become common practice among European national state agencies seeking to prevent entries by refugees from Africa across the Mediterranean Sea.

These very diverse formations-fisheries and the "high seas"-have existed for centuries, but they were either largely invisible to the formal eye of national state and interstate law (fisheries), or were developed and used for different purposes (the "high seas" in earlier periods). Specific assemblages of meaning-the environmental question and the fear of immigration-have had the power to bring them to the fore, and to make them the source of much legal ambiguity and conflict. They are intersections where different or new systems of rules generate new types of interpretation difficulties. Another such instance is privatizing governance through its contractualizing where this might once have been inconceivable, including transnationally. ${ }^{5}$ Notable examples of the current period are governing immigration through private contracts rather than state law.

In what follows I briefly conceptualize these diverse tensions and then examine several pertinent cases. I give particular attention to the large-scale acquisition of land by foreign government agencies and firms, an old process that expanded sharply after 2006 and reached over 200 million hectares by 2011 , only five years later. ${ }^{6}$ One substantive

3. Here are three articles, from a symposium in the MrCHIGAN JOURNAL OF INTERNATIONAL LAW, on natural resources and international law which address the issue of fisheries and jurisdiction. See generally Eric A. Bilsky, Conserving Marine Wildlife Through World Trade Law, 30 Mich. J. INT'L L. 599 (2009); John A. Duff, Assemblage-Oriented Ocean Resource Management: How the Marine Environment Washes over Traditional Territorial, 30 MiCH. J. INT'L L. 643 (2009); Ted L. McDorman, CanadaUnited States Cooperative Approaches to Shared Marine Fishery Resources: Territorial Subversion, 30 MICH. J. INT'L L. 665 (2009).

4. See Rowse, supra note 2 (discussing the term terra nullius).

5. See generally Peer Zumbansen, Introduction: Private Ordering in a Globalizing World: Still Searching for the Basis of Contract, 14 IND. J. GLOBAL LeGaL STUD. 181 (2007).

6. See Ward ANSEeuw, Liz Alden WILy, LoRenzo Cotula \& Michael Taylor, InT'L Land CoAlition, Land Rights and the Rush for land: Finding of the Global 
rationale for this focus is that it brings to the fore a tension between (a) the fact that interstate borders matter less today for many international flows and (b) the fact that this focus on open borders may be obscuring the new types of borderings and informal jurisdictions taking shape inside national territory. Elsewhere, ${ }^{7} \mathrm{I}$ posit that these developments contribute to constitute a multi-sited global space of a different sort from that of the self-evident global scale, which has received most of the attention. The former may well be as significant a transformation of our global age as is that global scaling and the weakening of most interstate borders; after all, interstate borders have long been crossed, lawfully or not, and imperial geographies have been part of the making of nation-states. ${ }^{8}$

These diverse developments, and others not discussed here, contribute to an emergent misalignment between territory and territoriality. While these two terms were never perfectly symmetricwith abundant instances of acute misalignment through colonialism and post-coloniality-it is nonetheless the case that the twentieth century saw the strengthening of alignment between territory and territoriality. But the past two decades have once again brought about more misalignments, some recognized and some not. The concern here is to detect holes in the tissue of national state sovereignty as traditionally constructed over the last century, the period that saw the rise of the capable, often powerful, administrative state, and as formalized in law. ${ }^{9}$

\section{Structural Holes In The Tissue of National State Authority}

There are two features that matter to this analysis, both of which I have emphasized in my prior work. ${ }^{10}$ First, sovereignty has been partly disassembled formally over the last twenty to thirty years, depending on the country. While much is still formally included in the national state and sited in national state territoriality, some of it has shifted to other institutional spaces, including global institutions such as the World Trade Organization (WTO), and private orderings that have taken over

Commercial Pressures on Land Research Project 4 (Tim Bending \& David Wilson eds., 2011) (It.).

7. SASKIA SASSEN, UNGOVERNED TERRITORIES (forthcoming 2013).

8. I develop this argument at length in Chapter 3 of TERRITORY, AUTHORITY, RIGHTS: From Medieval to Global Assemblages. SASSEN, supra note 1.

9. See Alfred C. Aman, JR., Administrative Law in a Global Era (1992); Alfred C. Aman, Jr., A Global Perspective on Current Regulatory Reform: Rejection, Relocation, or Reinvention?, 2 IND. J. GLOBAL LegaL STUD. 429 (1995) [hereinafter A Global Perspective on Current Regulatory Reform].

10. See SASkia SaSSEn, Losing Control? Sovereignty in AN Age of Globalization 1-32 (1996); SASSEN, supra note 1 , at 148-276. 
what was once under the aegis of international law. Besides the International Criminal Court (ICC) and the WTO, both public formalized domains that stand out, there is growing transnational contract law known as "contract governance." Peer Zumbansen writes that this is of rising interest for legal scholars due to the "increasing de-legalization and technicization of contract on the one hand and the proliferation of contractual governance in almost all sectors of societal life on the other."11

What is of particular interest to the argument in this paper is that once the shift to the private sphere has happened, the fact that these were components of state sovereignty is easily rendered invisible. My concern is not normative, but operational: how a system can render invisible its original aims and intentions and can alter the valence of a systemic capability. ${ }^{12}$ Past origins and performance are re-coded as elements of global "normative" orderings, dealing with global capitalism (WTO law, International Monetary Fund (IMF) conditionality, international accounting standards, and many others) or with the global commons, from human rights to the environment (far fewer, but we can single out the ICC). ${ }^{13}$ Many contribute to strengthen the legitimacy of private orderings, upheld as the proper way to do things-an extension of the legitimacy of the private sphere and of the norm that wherever possible we should have markets rather than governments enabling the work that needs to be done. Sovereignty remains a key systemic property, but its institutional bases are diversifying beyond the national

11. Zumbansen, supra note 5, at 185 . Another author that has worked extensively on privatization is Katharina Pistor. An informal circuit is also emerging in these private governance initiatives. Lori Nessel writes on "medical repatriation," which is the extrajudicial deportation of seriously ill migrant workers directly by hospitals. Rather than writing about this as an anomalous or exceptional occurrence, Nessel formulates this as a predictable outcome of the global undocumented labor market and the progressive privatization of immigration enforcement. See Lori A. Nessel, Disposable Workers: Applying a Human Rights Framework to Analyze Duties Owed to Seriously Injured or Ill Migrants, 19 IND. J. GLOBAL LEGAL STUD. 61 (2012).

12. See SASSEN, supra note 1, at 1-24, 401-24.

13. Transnational NGOs have emerged as significant actors in some of these domains. Sarah Phillips examines the ability of transnational NGOs to empower localized populations that are powerless by linking their appeals for rights at the national level to transnational human rights movements, using the case of disability rights in the Ukraine. See Sarah D. Phillips, Civil Society and Disability Rights in Post-Soviet Ukraine: NGOs and Prospects for Change, 16 IND. J. GLOBAL LEGAL STUD. 275 (2009). Joshua Reading looks at the privatization of healthcare in the global South as global NGOs and international relief agencies take over vital services once provided by the state. See Joshua P. Reading, Who's Responsible for This? The Globalization of Healthcare in Developing Countries, 17 IND. J. GLOBAL LEGAL STUD. 367 (2010). 
state. This diversifying is mostly invisible insofar as it shifts components of sovereignty to nonstate domains.

Secondly, even as globalization has expanded, state authority over its territory remains a key ordering in the international system. ${ }^{14}$ But, I argue, ${ }^{15}$ it does so with one difference; it now feeds, above all, the power of the executive branch of government, a power that has become increasingly privatized. Some components of the state's territorial authority, especially the regulatory and oversight responsibilities of the legislature, shift to other institutional homes, notably the market (privatization) and to an emergent jurisdiction of global regulators. ${ }^{16}$

Here I build on both of these earlier propositions, but the focus is different. I examine what is formally hidden by the ongoing dominance of territorial state authority, on the one hand, and by the growing contractualizing of governmental authority, on the other. The first conceptual move is to identify structural holes in the tissue of what we might describe as the formal (versus de facto) authority of the state. Another way of describing it is that the cages of national statehood are breaking, and that in a few instances this breakage becomes formally visible (e.g WTO law and ICC law) and in some other instances this visibility is material or derives from inference (e.g. the implications of large-scale land acquisitions by foreign government agencies and firms for a state's territorial authority). But in most cases the breakage is invisible to the eye of the law.

To capture the meaning and import of these developments, I posit that they can be conceived of as the making of informal jurisdictions. What I seek to capture either escapes established jurisdictions or worms itself into them and can easily be confused with them. ${ }^{17} \mathrm{I}$ also think of

14. An important issue for my analysis is the ongoing transformation of territoriality as a system of authority. Historically, Hannah Buxbaum notes that territoriality "referred to the exclusive authority of a state to regulate events occurring within its borders ... Over the course of the twentieth century, the concept expanded to include authority over certain conduct that took place elsewhere but whose effects were felt within the regulating state." Hannah L. Buxbaum, Territory, Territoriality, and the Resolution of Jurisdictional Conflict, 57 AM. J. CoMP. L. 631, 636 (2009). See also Hannah L. Buxbaum, IntroductionOperationalizing Global Governance, 16 IND. J. GLOBAL LEGAL STUD. 1, 1-5 (2009).

15. SASSEN, supra note 1 , at 1-24.

16. See A Global Perspective on Current Regulatory Reform, supra note 9, at 457-62.

17. In TERRITORY, AUTHORITY, RIGHTS, I first used this notion to capture material practices, which through their repetition, begin to make an informal jurisdiction. See SASSEN, supra note 1, at 31-73. I used the example of medieval traders and craftsmen who through their inter-city traveling had "produced a specific type of spatiality. This spatiality wormed its way into territories encased in multiple, formal, nonurban jurisdictions-feudal, ecclesiastical, and imperial." SASSEN, supra note 1, at 29. In chapter 5 , I describe a more abstract version of this process in discussing the installing of the needs of global finance and global firms in national state policies and laws from the $1980 \mathrm{~s}$ 
these informal jurisdictions as the equivalent of the terra nullius-that which was not mapped now becoming that which cannot be mapped in a world that is still formally divided into national state jurisdictions.

Such an inquiry requires a conceptual shift away from the borders of the nation-state as the site of change and of meaning. ${ }^{18}$ The overriding of borders is an important focus in the scholarship about the weakening of state authority over its territory. ${ }^{19}$ More generally, writing on the state has tended to focus on the battles to gain territory and the work of securing the sovereign's authority over its territory. ${ }^{20}$ As a result, in much scholarly writing, territory has largely ceased to work analytically because it has been reduced to a singular meaningnational territory. This emphasis is also evident in the scholarship focused on the partial overriding of state authority that came about with the formation of the global economy emerging in the $1980 \mathrm{~s}$, when nonstate actors and instruments gained influence over the state. This topic is one that I have examined elsewhere. ${ }^{21}$

There is a vast range of analyses and interpretations about the impacts of these new types of global regulators and global firms on the state's exclusive jurisdiction. ${ }^{22}$ Examples of structural holes in the

onwards, where they are dressed as norms originating in the interests of the state, for public benefit. See SASSEN, supra note 1, 222-76.

18. See generally Saskia Sassen, Bordering Capabilities Versus Borders: Implications for National Borders, 30 MICH. J. INT'L L. 567 (2009) (discussing through multiple examples how borders are moving away from traditional geographic borders and towards industry specific or activity specific boundaries).

19. See generally John Agnew, Hegemony: The New ShaPe of Global Power (2005); SASSEN, LOSING CONTROL? SOVEREIGNTY IN AN AGE of GlobalizaTION, supra note 10; James Anderson, The Shifting Stage of Politics: New Medieval and Postmodern Territorialities?, 14 ENV'T \& PLAN. D: SOC'Y \& SPACE 133 (1996); Paul Schiff Berman, The Globalization of Jurisdiction, 151 U. PA. L. REV. 311 (2002); Peter J. Taylor, The State as Container: Territoriality in the Modern World-System, 18 PROGRESS IN HUM. GEOGRAPHY 151 (1994).

20. See Eric Helleiner, States and the ReEmergence of Global Finance: From BRETTON WoOdS TO THE 1990S (1994); Stephen D. Krasner, Westphalia and All That, in IDEAS AND FOREIGN POLICY: BELIEFS, InSTITUTIONS, AND POLITICAL CHANGE 235 (Judith Goldstein \& Robert O. Keohane eds., 1993); Louis W. Pauly, Global Finance, Political Authority, and the Problem of Legitimation, in THE EMERGENCE OF PRIVATE AUTHORITY IN Global GoverNaNCE 76 (Rodney Bruce Hall \& Thomas J. Biersteker eds., 2002); LINDA WeIss, The MYTH OF THE POWERLEss State: Governing THE Economy IN a Global ERA (1998); Philip G. Cerny, Paradoxes of the Competition State: The Dynamics of Political Globalization, 32 Gov'T \& OPPOSITION 251 (1997); Eric Helleiner, Explaining the Globalization of Financial Markets: Bringing the State Back In, 2 REV.INT'L POL. ECON. 315 (1995).

21. SASSEN, supra note 1, 222-76.

22. This generated a strong and cross-disciplinary debate beginning in the $1990 \mathrm{~s}$ and continuing today about the traditional bases of state power and authority over its territory. See, e.g., Phillip G. Cerny, Structuring the Political Arena: Public Goods, States 
tissue of formal state authority over its territory abound, even though the language of structural holes is not used. I have selected some cases examined in the Indiana Journal of Global Legal Studies, yet another way of recognizing the Journal's twentieth anniversary. Let me state promptly and emphatically that the authors do not use the imagery I use nor are they concerned with the larger question I am after here. But it is perhaps precisely because of this that they are worth using as examples, to point to the breadth of treatment that this issue has been given even though the authors may have been after specific developments that do not correspond to my inquiry.

One area is the rise of corporate actors in transnational lawmaking. Till Müller ${ }^{23}$ looks at this area in general, Jane Levit ${ }^{24}$ explores it through the case of export credit, and Katharyne Michell and Katherine Beckett $^{25}$ through the case of transnational finance. Larry Backer, ${ }^{26}$ by contrast, argues that global surveillance activities have become a substitute for governance in the case of finance. Another area is explored by Tim Baines, ${ }^{27}$ who looks at the voluntary participation of transnational corporations (TNCs) in transnational social responsibility initiatives. Gustavo Ribero ${ }^{28}$ similarly examines the links between voluntary participation in transnational corporate social responsibility

and Governance in a Globalizing World, in Global POLITICAL ECONOMY: CONTEMPORARY THEORIES 21 (Ronen Palan ed., 2000); Stephen Gill, Globalization, Democratization, and the Politics of Indifference. in GlobalizATION: CRITICAL REFLECTIONS 205 (James H. Mittelman ed., 1996); ReImagining the Future: Critical PERsPectives on Global GOVERNANCE (Stephen Gill ed., forthcoming 2013); GLOBALIZATION THEORY: APPROACHES AND ConTroversies (David Held \& Anthony McGrew eds., 2007); PaUL HIRST \& GRAHAME THOMPSON, GLOBALIZATION IN QUESTION: THE INTERNATIONAL ECONOMY AND THE PossibILities of Governance (1996); Eric Helleiner, Sovereignty, Territoriality and the Globalization of Finance in STATES AND SOVEREIGNTY IN THE GLOBAL ECONOMY (David A. Smith, Dorothy J. Solinger \& Steven C. Topik eds,, 1999); ComPaRATIVE LAW AS Transnational Law: A Decade of the German Law Journal (Russel A. Miler \& Peer C. Zumbansen eds., 2011); Pauly, supra note 20.

23. Till Müller, Customary Transnational Law: Attacking the Last Resort of State Sovereignty, IND. J. GLOBAL LEGAL STUD. 19 (2008).

24. Janet Koven Levit, Bottom-Up Lawmaking: The Private Origins of Transnational Law, 15 IND. J. GLOBAL LEGAL STUD. 49 (2008).

25. Katharyne Mitchell \& Katherine Beckett, Securing the Global City: Crime, Consulting, Risk, and Ratings in the Production of Urban Space, 15 IND. J. GLOBAL LEGAL STUD. 75 (2008).

26. Larry Catá Backer, Global Panopticism: States, Corporations, and the Governance Effects of Monitoring Regimes, 15 IND. J. GLOBAL LEGAL STUD. 101 (2008).

27. Tim Baines, Integration of Corporate Social Responsibility Through International Voluntary Initiatives, 16 IND. J. GLOBAL LEGAL STUD. 223 (2009).

28. Gustavo Ferreira Ribeiro, Navigating the Turbulent Waters Connecting the World Trade Organization and Corporate Social Responsibility, 16 IND. J. GLOBAL LEGAL STUD. 249 (2009). 
initiatives and WTO enforcement regimes. Gunther Teubner ${ }^{29}$ examines the linkages between private and public legal regimes in the governance of TNCs, finding that national law often fails to exercise binding force on the behavior of TNCs, in contrast to voluntary participation in private codes of conduct, which he argues are emergent transnational regimes; at the same time, public state actors have been key in facilitating the rise in private regulation through their promotion of free markets.

These and other developments have led to a conceptual repositioning of the concept of the state's territorial authorityterritoriality. ${ }^{30}$ But overall it remains close to its original intended meaning, exclusive state sovereign power over its territory. Kal Raustiala criticizes what he labels "legal spatiality," namely the notion that "[t]he scope and reach of the law is connected to territory, and therefore, spatial location determines the operative legal regime." 31 There are many more such indications of a misalignment between territory and territoriality.

I use such misalignments to examine what the imperfect scope and reach of the law can make visible in terms of structural holes in the jurisdiction of national sovereign territory. One mode this misalignment takes is to operate or oscillate between formal and informal global governance. An example is that of transnational environmental governance. Brian Winchester writes on the increasing interplay between state and nonstate actors (e.g. NGOs and activist networks) in the development of transnational environmental regulations, resulting in a version of global governance that is more complex than simple international agreements. ${ }^{32}$ Tun Myint ${ }^{33}$ also writes on the interplay of state and nonstate actors in global environmental governance, with a focus on transnational institutions. Michael Ewing-Chow and Darryl Soh, ${ }^{34}$ meanwhile, examine the shift from a focus on cooperation and coordination between states in international environmental agreements

29. Gunther Teubner, Self-Constitutionalizing TNCs? On the Linkage of "Private" and "Public" Corporate Codes of Conduct, 18 IND. J. GLOBAL LEGAL STUD. 617 (2011).

30. See generally Comparative LaW as TRansnational LaW: A DeCade of the German Law Journal, supra note 22; A Global Perspective on Current Regulatory Reform, supra note 9.

31. Kal Raustialia, The Geography of Justice, 73 FORDHAM L. REv. 2501, 2506 (2005).

32. N. Brian Winchester, Emerging Global Envirunmental Governance, 16 IND. J. GLOBAL LEGAL STUD. 7 (2009).

33. Tun Myint, Globalization and the Institutional Dynamics of Global Environmental Governance, 18 IND. J. GLOBAL LEGAL STUD. 395 (2011).

34. Michael Ewing-Chow \& Darryl Soh, Pain, Gain, or Shame: The Evolution of Environmental Law and the Role of Multinational Corporations, 16 IND. J. GLOBAL LEGAL STUD. 195 (2009). 
to a focus on enforced compliance in global environmental regulation. In the latter, corporations, rather than states, are the primary targets for transnational environmental legal regimes.

The dilution of the state's formal power over its territory tends to take on specific forms and produce specific redistributions of power across diverse state branches. One such specific form is the case of national legislative jurisdictions losing their grip on a growing range of domains over which they once had regulatory power, or at least formal authority. One mode of adapting to this loss has been precisely to pass laws that deregulate and privatize what was once regulated and public. That was a short burst of lawmaking that had the effect of shrinking the domain where legislatures were the key state branch..$^{35}$ Deregulation and privatization have led to a widespread understanding that the "national-state" loses authority with globalization. 36 Elsewhere, ${ }^{37}$ I have examined how even as corporate globalization reduced the power of national legislative jurisdiction, it enabled a relatively greater concentration of unaccountable power in the executive.

Next I turn briefly to three examples that are part of the larger project on which this essay is based.

\section{EMERGENT JURISDICTIONS}

\section{A. Extraterritorial Immigration Control Through Interdiction of Vessels at Sea}

Article $33(1)$ of the 1951 Convention relating to the Status of Refugees, which covers non-refoulement, holds that "[n]o Contracting State shall expel or return ('refouler') a refugee in any manner whatsoever to the frontiers of territories where his life or freedom would be threatened on account of his race, religion, nationality, membership of a particular social group or political opinion." 38 A number of countries

35. E.g., A Global Perspective on Current Regulatory Reform, supra note 9.

36. For a discussion of the state focusing on battles to gain territory and securing the sovereign's authority, see generally HELLEINER, supra note 20; Krasner, supra note 20; Pauly, supra note 20; WEISS, supra note 20; Helleiner, supra note 20; Cerny, supra note 20.

37. SASSEN, supra note 1, 148-221.

38. Convention Relating to the Status of Refugees, July 28, 1951, 189 U.N.T.S. 150, Art. 33, 1 (emphasis added), available at http://www.unhcr.org/protect/PROTECTION/ 3b66c2aa10.pdf. For articles discussing the Convention, see Andrew Brouwer \& Judith Kumin, Interception and Asylum: When Migration Control and Human Rights Collide, 21 REFUGE, no. 4, at 6 (2003), available at http://pi.library.yorku.ca/ojs/index.php/refuge/ article/viewFile/21305/19976; Thomas Gammeltoft-Hansen, The Refugee, the Sovereign 
interdict or intercept ships carrying irregular migrants at sea as a way of evading their obligation of non-refoulement in the practice of immigration control. ${ }^{39}$

Interdiction of irregular migrants at sea variously involves either transferring migrants to extraterritorial migration processing centers, so-called "push-backs" or "tow-backs," where ships are forced back into international waters (prohibited from entering territorial waters) or physically towing the vessels all the way back to the country of departure. In the case of the former, the transfer of irregular migrants to extraterritorial migration processing centers allows states to evade their own national laws regarding immigration protections, while ostensibly adhering to international refugee law in cases of asylum seeking. ${ }^{40}$ Moreover, in cases where asylum is granted, migrants can be resettled in third countries rather than in the country to which they

and the Sea: EU Interdiction Policies in the Mediterranean, (Danish Institute for International Studies, Working Paper No. 2008/6, 2008), available at

http://www.diis.dk/graphics/Publications/WP2008/WP08-

6_Refugee_Sovereign_Sea_EU\%20Interdiction_Policies_Mediterranean.pdf (arguing that it is "the growing trend in the EU of enacting migration control at the high seas or international waters-so-called interdiction. It is argued that these forms of extraterritorial migration control aim at reconquering the efficiency of the sovereign function to control migration.").

39. In introducing interdiction, Bernard Ryan offers two primary cases: unauthorized Jewish arrivals in Palestine in the late 1930s and Vietnamese "boat people" in 1975-1992. Bernard Ryan, Extraterritorial Immigration Control: What Role for Legal Guarantees?, in EXTRATERRITORIAL IMMIgRation CONTROL: LEGAL CHALlEnges 22-24 (Bernard Ryan \& Valsamis Mitsilegas eds., 2010). See also ElEANOR TAYLOR NICHOLSON, THE CHIEF JUST. EARL WARREN INST. L. \& SOC. POL'Y, CUTTING OFF THE FLOW: EXTRATERRITORIAL CONTROLS TO PREVENT MIGRATION 2 (2011), available at http://eucenter.berkeley.edu/files/ Issue_Brief_2011_Final.pdf ("This issue brief explores the extent to which the United States, Europe and European governments have implemented different extraterritorial controls."); Seline Trevisanut, The Principle of Non-Refoulement at Sea and the Effectiveness of Asylum Protection, 12 MAX PLANCK Y.B.U.N.L. 205 (A. von Bogdandy \& R. Wolfrum eds., 2008), available at http://www.mpil.de/shared/data/pdf/pdfmpunyb/ 05_trevisanut_12.pdf ("This article elucidates how the exercise of sovereign powers in different maritime zones pursuant to the law of the sea and customary international law gives rise to challenges in the application of the principle of non-refoulement and in the protection of asylum-seekers and refugees at sea. Particular attention must be given to the so-called non-reentrée mechanisms made principally to prevent a refugee from having access to the procedures for the determination of his/her status. Among those are the interdiction at sea programs.").

40. See Brouwer \& Kumin, supra note 38. Here is a quote from UNHCR: "Many States which have the ability to do so find that intercepting migrants before they reach their territories is one of the most effective measures to enforce their domestic migration laws and policies." United Nations High Commissioner for Refugees, Refugee Protection and Migration Control: Perspectives from UNHCR and IOM, UN Doc. EC/GC/01/11 ף14 (May 31, 2001), available at http://www.unhcr.org/refworld/pdfid/3b3701b813.pdf. 
were originally headed. ${ }^{41}$ In the case of the latter, interdicting countries effectively turn over their responsibilities toward irregular migrants under international law to the country of departure based on specific agreements in place with the country of departure..$^{42}$

\section{U.S. Interdiction Practices}

The United States practices a "wet foot/dry foot" approach to interdiction of irregular migrants within U.S. territorial waters, under which the protections of the Immigration and Nationality Act of 1952 are deemed to apply only to migrants who reach the shore. ${ }^{43}$ Outside of its territorial waters-at high sea and in the territorial waters of other countries, pursuant to official agreements-U.S. interdiction policies have been in effect since 1981 for ships without a flag or where the United States has an agreement in place with a flag state. ${ }^{44}$ U.S. Coast Guard interdiction is concentrated in the Caribbean and has included regular patrols of the Windward Passage (between Haiti and Cuba) since 1981, the Straits of Florida since 1994, and the Mona Passage (between the Dominican Republic and Puerto Rico) since 1995. ${ }^{45}$ From

41. See Ryan, supra note 39 , at 3 .

42. For an article offering a good explanation of the issues at stake in the case, even though focused on Italy, see Violeta Moreno-Lax, Hirsi Jamaa and Others $v$ Italy or the Strasbourg Court versus Extraterritorial Migration Contral?, 12 HuM. RTS L. REV. 574 (2012). For the judgment, see Hirsi Jamaa and Others v. Italy, Eur. Ct. H.R. App. no. 27765/09 (2012), available at http:/www.unhcr.org/refworld/docid/ 4f4507942.html.

43. Immigration and Nationality Act, 8 U.S.C. $\$ 1101-1537$ (2013). For an article discussing the Act, see generally Niels Frenzen, US Migrant Interdiction Practices in International and Territorial Waters, in EXTRATERRITORIAL IMMIGRATION CONTROL: LEGal Challenges, supra note 39, at 375. For an article going through the policy regarding Cubans and Haitians, see Alberto J. Perez, Wet Foot, Dry Foot, No Foot: The Recurring Controversy Between Cubans, Haitians, and the United States Immigration Policy, 28 Nova L. REV. 437, 454 (2004). Here is a pertinent quote: "I have made it abundantly clear to the Coast Guard that we will turn back any refugee that attempts to reach our shore." Bill Frelick, "Abundantly Clear": Refoulment, 19 GEO. IMMIGR. L.J. 245, 245(2004) (quoting President George W. Bush speaking on Feb. 25, 2004). See also Trevisanut, supra note 39 , at 221 .

44. See Ryan, supra note 39 , at 25 . For an article written by a Captain in the U.S. Coast Guard citing much of the case law around interdiction operations at sea through 1996, see Gary W. Palmer, Guarding the Coast: Alien Migrant Interdiction Operations at Sea, 29 Conn. L. REv. 1565 (1997). See also Louis B. Sohn, Interdiction of Vessels on the High Seas, 18 INT'L LAW. 411 (1984) (starting with President Reagan's September 29, 1981 proclamation declaring that the "entry of undocumented aliens from the high seas is hereby suspended and shall be prevented by the interdiction of certain vessels carrying such aliens.").

45. Ryan, supra note 39 , at 24; Palmer, supra note 44 . Let me clarify that Coast Guard interdiction was for the purposes of both migration and drug trafficking. Missions: 
1982-2009, 114,718 Haitian, 66,702 Cubans, and 25,756 Dominicans have been interdicted in these operations. ${ }^{46}$ In similar operations in the Pacific, 5,912 Chinese nationals (mostly headed to Guam) and 8,257 Ecuadorian nationals-among others-have been interdicted since the late 1990 s. ${ }^{47}$

Where there is a specific agreement in place, as there is with Haiti for example, interdicted migrants are immediately returned to the country of departure. ${ }^{48}$ In other cases, ships are "pushed back" to international waters. ${ }^{49}$ To avoid violating the non-refoulement principle of international law, which applies within territorial waters (and potentially beyond as discussed in the case of Italy below), the United States transfers those interdicted in its territorial waters, as well as those claiming protection (whether in territorial waters or at high sea), to extraterritorial processing centers such as Guantánamo Bay. ${ }^{50}$ In Sale vs. Haitian Centers Council, decided in 1993, the U.S. Supreme Court upheld the U.S. practice of interdiction at high sea by ruling that the prohibition of non-refoulement did not apply extraterritorially. ${ }^{51}$ Notably, irregular migrants interdicted by the U.S. Coast Guard en route from Cuba or China are automatically informed of their right to appeal for protection, whereas migrants from other places must spontaneously make such a request. 52

\section{Australian Interdiction Practices}

Australia has used U.S. interdiction policy as a model for its own practices, most notably those of the Howard government, which included "tow-backs" and the notorious "Pacific Solution" practiced from 2001-2007.53 These so-called "tow-backs" involved the interdiction of

Maritime Safety, U.S. COAST GUARD, http://www.uscg.mil/top/missions/ MaritimeSecurity.asp (last visited Mar. 24, 2013).

46. Ryan, supra note 39, at 24-25. These numbers come from Ryan's accessing U.S. Coast Guard statistics on Nov. 3, 2009. See US Coast Guard, Alien Migrant Interdiction: Total Interdictions-Fiscal Year 1982 to Present, http://www.uscg.mil/hq/cg5/cg531/AMIO/ FlowStats/FY.asp (last visited Mar. 24, 2013).

47. Ryan, supra note 39 , at 25 .

48. Id. at 27.

49. See Trevisanut, supra note 39, at 241; Frelick, supra note 43, at 257.

50. Ryan, supra note 39 , at 26 .

51. Jan Arno Hessbruegge, European Court of Human Rights Protects Migrants Against 'Push Back" Operations on the High Seas, AM. SOC'Y INT'L L. INSIGHTS (Apr. 17, 2012), http://www.asil.org/insights120417.cfm.

52. Frenzen, supra note 43.

53. See Penelope Mathew, Legal Issues Concerning Interception, 17 GEO. IMMIGR. L.J. 221, 221 (2003); Tara Magner, A Less than 'Pacific' Solution for Asylum Seekers in Australia, 16 INT'L J. REFUGEE L. 53 (2004). 
ships en route from Indonesia, which were then towed by Australian authorities back to Indonesian shores in accordance with specific agreement with the Indonesian government. ${ }^{54}$ The Pacific Solution, implemented in cases where ships were carrying asylum seekers from places like Afghanistan, Pakistan, or Sri Lanka, involved transferring interdicted irregular migrants to extraterritorial immigration processing centers on Nauru and Manus Islands in Papua New Guinea.

The Pacific Solution was ended by the Rudd government shortly after it took power and, starting in 2008, migrants interdicted at sea have been transferred to the offshore processing center on Australia's Christmas Island. ${ }^{55}$ This is a place where irregular migrants can access lawyers and interpreters, however, "the fact that Christmas Island is 'excised' from the migration zone means that their claims continue to be assessed outside of the standard legal mechanisms governing asylum claims." 56

\section{Italy's Interdiction Practices and the 2012 ECtHR Ruling Against It}

Since the 1990s, Italy has been interdicting ships carrying irregular migrants. However, until early 2009 , migrants were generally permitted to land and have any asylum claims processed before being repatriated. ${ }^{57}$ However, in May 2009 Italy began practicing "push-backs" wherein coastal authorities would interdict ships departed from Libya carrying irregular migrants on the high seas, take migrants

54. See generally Susan Kneebone, Controlling Migration by Sea: The Australian Case, in EXTRATERRITORIAL IMMIGRATION CONTROL: LEGAL CHALLENGES, supra note 39, at 347.

55. Ryan, supra note 39, at 29. Here, Ryan is drawing on several newspaper reports, among which: Craig Skehan, Pacific Solution Ends but Tough Stance to Remain, SYDNEY MORNING HERALD, Dec. 8, 2007, available at http://www.smh.com.au/news/national/pacific-solution-ends-but-tough-stance-toremain/2007/12/07/1196813021259.html; Refugee Status Given to Burmese; Swift end to 'Pacific Solution,' THE AGE, Dec. 10, 2007; David Crawshaw, Government Denies Back Flip on Island Excision, THE AGE, Feb. 21, 2008, available at http://news.theage.com.au/national/govt-denies-backflip-on-island-excision-200802211tmq.html.

56. Ryan, supra note 39 , at 29. Ryan refers the reader to another chapter in the volume: Kneebone, supra note 54. See also Brouwer \& Kumin, supra note 38. Here is an illuminating quote from UNHCR that begins that article: "Many States which have the ability to do so find that intercepting migrants before they reach their territories is one of the most effective measures to enforce their domestic migration laws and policies." United Nations High Commissioner for Refugees, Refugee Protection and Migration Control: Perspectives from UNHCR and IOM, supra note 40.

57. See Alessia di Pascale, Migration Control at Sea: The Italian Case, in EXTRATERRITORIAL IMMIGRATION CONTROL: LEGAL CHALLENGES, supra note 39, at 281. 
onboard, and return them directly to Libya without investigating possible claims for protection or even determining nationality (many irregular migrants coming from Libya were from third-world countries in sub-Saharan Africa).58 Thus, a group of Somali and Eritrean migrants turned over to Libyan authorities by Italian authorities brought their case to the European Court of Human Rights (ECtHR) in Hirsi Jamaa et al. $v$. Italy. ${ }^{59}$

In their decision on Hirsi Jamaa et al. v. Italy, delivered on February 23, 2012, the ECtHR judges hearing the case unanimously ruled that Italy had failed to uphold its obligations to protect the applicants from torture and inhumane or degrading treatment under Article 3 of the European Convention and from the collective expulsion of non-nationals, ${ }^{60}$ even though the applicants never reached Italy's territorial water. This decision effectively extended European human rights law extraterritorially.

The ECtHR's ruling falls in line with The United Nations High Commissioner for Refugees' (UNHCR) long held position that non-refoulement applies in cases where refugees and persons in need of protection fall under the effective control of a state acting outside of its territory (including territorial waters). ${ }^{61}$ The ECtHR decision also noted that Italy put applicants at risk of secondary refoulement as Libya might have arbitrarily repatriated them as Libya, under Qaddafi, did not observe international refugee law. While the refoulement decision was expected, the finding that Italy violated the prohibition on collective expulsion was less so. As reporter Jan Hessbruegge explains,

58. Ryan, supra note 39 , at 31.32 .

59. Hirsi Jamaa and Others v. Italy, Eur. Ct. H.R. App. no. 27765/09 (2012), available at http://www.unhcr.org/refworld/docid/4f4507942.html.

60. Protocol No. 4 to the Convention for the Protection of Human Rights and Fundamental Freedoms art. 4, May 2, 1968, E.T.S. No. 46; for the reasons for this decision, see Hirsi Jamaa and Others, Eur. Ct. H.R. App. no. 27765/09 at 57-59. The European Court of Human Rights fact sheet on Expulsions and extraditions summarizes the Article violations in the Hirsi Jamaa et al v. Italy case. See Expulsions and Extraditions, EUR. CT. H.R. (Feb. 2013), http://www.echr.coe.int/NR/ rdonlyres/211A6F9C-A4EC-4CF7-AB2E-

42E9D49FB2EF/0/FICHES_Expulsions_et_extraditions_EN.pdf.

61. See generally U.N. High Commissioner for Refugees, UNHCR's Oral Intervention at the European Court of Human Rights-Hearing of the Case Hirsi and Others v. Italy (June 22, 2011), available at http://www.unhcr.org/refworld/docid/4e0356d42.html; written intervention by U.N. High Commissioner for Refugees to U.N. Eur. Ct. H.R., Submission by the Office of the United Nations High Commissioner for Refugees in the Case of Hirsi and Others $v$. Italy (Mar. 29, 2011), available at http://www.unhcr.org/refworld/docid/ 4d92d2c22.html; Intervener Brief for U.N. High Commissioner for Human Rights, Hirsi Jamaa and Others v. Italy, Eur. Ct. H.R. App. no. 27765/09 (2011), available at http://www.unhcr.org/refworld/docid/4f5f11a52.html. 
Insisting on the ordinary sense of the word "expulsion," Italy strenuously argued that only a person who had actually reached the state's territory could be subject to expulsion. The prohibition of collective expulsion, Italy advanced, only came into play when individuals already within the territory of a state, or those who had crossed the national border illegally, were expelled. Conversely, the applicants took the position that pushing back migrants on the high seas could constitute hidden expulsions. They also noted that Italian law considered ships flying the Italian flag to be Italian territory, which implied that removing the applicants from the Italian coast guard vessels was tantamount to expelling them from Italian territory. ${ }^{62}$

As well as extending European human rights law extraterritorially to include European ships at sea, the ECtHR ruling in the Hirsi case against collective expulsion implicated the failure of Italian officials to individually assess irregular migrants' protection claims. ${ }^{63}$ Accordingly, the ruling found that "push back operations without such individualized assessment are therefore generally illegal, regardless of where the victims are pushed back (e.g., a place like Libya under Qaddafi or another, more secure state)."64

\section{B. U.S. Overseas Military Bases-Infrastructure and Jurisdiction}

\section{U.S. Military Infrastructure Abroad}

The United States maintains the most extensive network of foreign military bases in the world. The Pentagon's published numbers put the total number of U.S. military bases abroad at $750 .{ }^{65}$ However, this

62. Hessbruegge, supra note 51 , at 3 .

63. For discussion of the "individual assessment" issue, see EUROPEAN COMMITTEE FOR THE PREvention of TORTURE AND INHUMAN OR DEgRading TREaTMENT OR PUNISHMENT, 22ND GENERAL REPORT OF THE CPT 17 (2012), available at http://www.cpt.coe.int/en/annual/rep-22.pdf; Hirsi Jamaa and Others v. Italy, Eur. Ct. H.R. App. no. 27765/09 at 52-53 (2012), available at http://www.unhcr.org/refworld/docid/ 4f4507942.html (discussing in the section labeled third party interveners).

64. Hessbruegge, supra note 51 , at 4 .

65. Cora Fabros, BASES OF EMPIRE: The Global Spread of U.S. Military and Intelligence Bases, CONVERGE (2008),

http://www.converge.org.nz/abc/pr37-1721.html (providing the average number of bases from 2003 to 2005 at a figure of more than 750 based upon the 2005 U.S. Department of Defense publication Base Structure 2005). There has been considerable change in the logic 
number does not include any entries for bases in Afghanistan due to the ongoing conflict there, leading some to estimate the total number of foreign bases at over $1,000.66$ In either case, this is a massive network that spans every continent (including Antarctica) and includes eleven aircraft carriers at sea (essentially floating bases), and even a growing military infrastructure in space. Using just the official Pentagon numbers, reporter Nick Turse writes,

What we do know is that, on the foreign outposts the U.S. military counts, it controls close to 52,000 buildings, and more than 38,000 pieces of heavy infrastructure like piers, wharves, and gigantic storage tanks, not to mention more than 9,100 "linear structures" like runways, rail lines, and pipelines. Add in more than 6,300 buildings, 3,500 pieces of infrastructure, and 928 linear structures in U.S. territories and you have an impressive total. ${ }^{67}$

While in recent years the United States has been downsizing its largest military bases-the city-sized bases from the Cold War era in countries like Germany and South Korea-it has been quietly expanding its network of smaller bases around the world. ${ }^{68}$ These so-called "lily pad bases" (picture a frog hopping from lily pad to lily pad as it makes its way around a pond) are described by anthropologist David Vine as becoming "a critical part of an evolving Washington military strategy aimed at maintaining U.S. global dominance by doing far more with less in an increasingly competitive, ever more multi-polar world."69 The expansion of these smaller lily pad bases makes it harder

of basing since, with new types of bases added and older types closed. See DEP'T OF DEF., BASE STRUCTURE REPORT FISCAL YEAR 2012 BASELINE (2012), available at http://www.acq.osd.mil/ie/download/bsr/BSR2012Baseline.pdf [hereinafter DEP'T OF DEF.].

66. See Nick Turse, Tomgram: Nick Turse, The Pentagon's Planet of Bases, TOMDISPATCH (Jan. 9, 2011, 5:13 PM), http://www.tomdispatch.com/blog/175338/ tomgram\%3A_nick_turse\%2C_the_pentagon\%27s_planet_of_bases (providing a detailed accounting of how different estimates of the total number of U.S. military bases abroad have been calculated by various officials and journalists).

67. Id.

68. David Vine, Tomgram: David Vine, U.S. Empire of Bases Grows, TOMDispatch (July 15, 2012, 5:32 PM), http://www.tomdispatch.com/archive/175568 ("While the collection of Cold War-era giant bases around the world is shrinking, the global infrastructure of bases overseas has exploded in size and scope."). A discussion of military bases by size for fiscal year 2011 appears in DEP'T OF DEF., supra note 65, at 23-33.

69. David Vine, supra note 68 (discussing the "lily-pad" strategy). See also Ann Scott Tyson, New US Strategy: 'Lily Pad' Bases, Christian SCI. Monitor (Aug. 10, 2004), http://www.csmonitor.com/2004/0810/p06s02-wosc.html. 
to get a precise count of U.S. military bases abroad, as bases less than ten acres or valued at less than $\$ 10$ million are either aggregated into a single entry or not counted at all in the Pentagon's official numbers. Moreover, some lily pad bases are ostensibly temporary and some are secret, or "black sites," making the total number impossible to count. ${ }^{70}$

\section{Jurisdiction over U.S. Military Personnel and Contractors Abroad}

For permanent military bases outside of warzones, precise details of criminal jurisdiction over U.S. military personnel, their dependents, and civilians working on the bases are presented in Status of Forces Agreements (SOFAs) set-up between the United States and the host nation on an individualized basis. ${ }^{71}$ However, in many so-called "black-sites" and "lily pad" bases, there are no SOFAs in place. ${ }^{72}$ In such situations, the U.S. Uniform Code of Military Justice (UCMJ)-the martial courts system-and the Military Extraterritorial Jurisdiction Act of 2000 (MEJA) extend U.S. military and civilian jurisdiction, respectively, outside U.S. territory. ${ }^{73}$

The UMCJ applies to all military personnel within, as well as outside of, U.S. territory, effectively extending U.S. military jurisdiction to cover U.S. military personnel wherever they are located. ${ }^{74} \mathrm{MEJA}$, meanwhile, extends U.S. federal (civilian) jurisdiction broadly to cover offenses committed outside of U.S. territory such that all persons "employed by or accompanying the Armed Forces" overseas can be prosecuted for any offense punishable by at least one year. ${ }^{75} \mathrm{MEJA}$ covers civilians accompanying the U.S. military (such as dependents) or those directly employed by the Department of Defence (DoD), as well as

70. DEP'T OF DEF., supra note 65 , at 4 ("To qualify for individual entry in the BSR, a DoD site located in the United States must be larger than 10 acres AND have a Plant Replacement Value (PRV) greater than $\$ 10$ million. If the site is located in a foreign country, it must be larger than 10 acres OR have a PRV greater than $\$ 10$ million to be shown as a separate entry.").

71. For a detailed discussion of SOFAs see R. CHUCK MASON, CONGRESSIONAL Research Service Pub. No. RL34531, Status of Forces AGreement (SOFA): What Is IT, AND HOW HAS IT BEEN UTILIZED (2012).

72. See Mason, supra note70, at 8.

73. Uniform Code of Military Justice, 10 U.S.C. ch. 47 (2013).

74. 10 U.S.C. $\S 802$ (2013) (listing the persons subject to the Uniform Code of Military Justice).

75. 18 U.S.C. $\$ 3261$ (2013) ("Criminal offenses committed by certain members of the Armed Forces and by persons employed by or accompanying the Armed Forces outside the United States" are included in the extraterritorial jurisdiction). 
private military contractors and subcontractors of the DoD. ${ }^{76}$ In October 2004, MEJA was expanded to include civilian employees of other federal agencies or "any provisional authority" whose employment is related to or in support of the DoD. ${ }^{77}$ In 2007, the U.S. House of Representatives passed the MEJA Expansion and Enforcement Act of 2007 (MEJA Expansion Act), which would have extended the reach of MEJA to all contractors in an area where the Armed Forces were conducting a contingency mission regardless of whether or not they were associated with the DoD. ${ }^{78}$ However, the bill did not pass the Senate. ${ }^{79}$

However, whether or not the MEJA Expansion Act had been passed, it is unlikely that it would have led to more effective prosecution of civilian contractors abroad. To prosecute contractors for crimes committed overseas under MEJA, U.S. federal investigators have to gather evidence in far off places, including dangerous warzones, where there are likely to be access and language barriers, as well as practical difficulties in gathering evidence weeks or even months after an offense was committed. As Peter W. Singer notes, MEJA assumes that civilian prosecutors have the resources and motivation to investigate and prosecute offenses committed overseas when " $[t]$ he reality is that no US Attorney likes to waste limited budgets on such messy, complex cases 9,000 miles outside their district, even if they were fortunate enough to have the evidence at hand." 80 Katherin Chapman also points out, with regards to MEJA, that the U.S. military is increasingly dependent on private contractors, and "[w]ith such a strong reliance on these contractors, federal investigators and prosecutors may face pressure to not fully investigate or prosecute cases." 81 The only successful

76. Id. See also Marc Lindemann, Civilian Contractors Under Military Law, PARAMETERS (2007), available at http:/www.carlisle.army.mil/usawc/parameters/Articles/ 07autumn/lindeman.pdf.

77. This change was made through the FY 2005 DoD Authorization Act. For a very detailed (though authored by the military) summary of what the 2004 change was designed to do, see Glenn R. Schmitt, Amending the Military Extraterritorial Jurisdiction Act (MEJA) of 2000: Rushing to Close an Unforeseen Loophole, ARMY LAW, June 2005, at 41.

78. MEJA Expansion and Enforcement Act of 2007, H.R. 2740, 110th Cong. (2007).

79. "This bill was introduced in a previous session of Congress and was passed by the House on October 4, 2007 but was never passed by the Senate." MEJA Expansion and Enforcement Act of 2007, GovTrack.US, http://www.govtrack.us/congress/bills/110/hr2740 (last visited Mar. 23, 2013).

80. Peter W. Singer, The Law Catches Up to Private Militaries, Embeds, BRookINGS (Jan. 4, 2007), http://www.brookings.edu/research/articles/2007/01/04defenseindustrysinger.

81. Katherin J. Chapman, The Untouchables: Private Military Contractors' Criminal Accountability Under the UCMJ, 63 VAND. L. REv. 1047, 1065 (9th Cir. 2010). 
prosecution carried out under MEJA involved the stabbing of a U.S. soldier by his wife on a military base in Turkey. ${ }^{82}$

Before 2007, military contractors were subject to UCMJ only in situations where Congress had declared war-which it has not done since WWII. ${ }^{83}$ However, the UCMJ was expanded in the 2007 Military Authorization Act to cover civilian contractors employed in military contingency operations abroad. ${ }^{84}$ This closes a significant loophole wherein private military contractors could commit crimes abroad with impunity, despite the applicability of MEJA in such cases. However, it remains to be seen how UCMJ will be applied to civilian contractors abroad and whether the application of military rule to civilians will raise any constitutional challenges.

\section{The Partial Disassembling of National Territory}

The acquisition of land by foreign governments and foreign firms is a centuries-old process in much of the world. But we can detect specific phases in these long and diverse histories. In this essay I focus on the most recent phase in this long history: the rapid and sharp increase in foreign land acquisitions beginning in 2006. While this can be seen merely as a continuation of an old practice, the available evidence points to significant change in the curve describing the size of overall acquisitions. ${ }^{85}$ From 2006 to 2010 , over 70 million hectares of land were

82. United States v. Arnt, 474 F. 3d 1159 (2007). For an article discussing the case see Sara Catania, Death at Incirlik, LEGAL AFF., Nov.-Dec. 2004, available at http:/www.legalaffairs.org/issues/November-December-2004/story_catania_novdec04.msp.

83. Lindemann, supra note 76 , at 83.

84. The change was to Article 2 of the UCMJ-expanding from war to "war or a contingency operation." 10 U.S.C. $\S 802(10)$ (2013). For an article specifically about the implication of changing "war" to "declared war or a contingency operation" see Peter W. Singer, The Law Catches Up to Private Militaries, Embeds, BRoOKINGS (Jan. 4, 2007), http://www.brookings.edu/research/articles/2007/01/04defenseindustry-singer.

85. See generally WARD ANSEEUW ET AL., TRANSNATIONAL LAND DEALS FOR AGRICULTURE IN THE GLOBAL SOUTH: ANALYTICAL REPORT BASED ON THE LAND MATRIX DATABASE (2012), available at http://www.landcoalition.org/sites/default/files/publication/ 1254/Analytical\%20Report\%20Web.pdf; SATURINO M. BORRAS JR. ET AL., LAND GRABBING IN LATIN AMERICAN AND THE CARIBBEAN VIEWED From BROADER INTERNATIONAL PERSPECTIVES (2011), available at http:/www.tni.org/sites/www.tni.org/files/download/ borras_franco_kay_spoor_land_grabs_in_latam_caribbean_nov_2011.pdf; LORENZO COTULA, INT'L LAND COAL., COMMERClal PRESSURES ON LAND: THE OUTLOOK ON FARMLAND ACQUISITIONS (2011), available at http://www.ibcperu.org/doc/isis/13570.pdf; KLAUS DEININGER ET AL., RISING GLOBAL INTEREST IN FARMLAND: CAN IT YIELD SUSTAINABLE AND EQUTTABLE BENEFTTS? (2011), available at http://siteresources.worldbank.org/ INTARD/Resources/ESW_Sept7_final_final.pdf; U.N. CONF. ON TRADE \& DEV., WORLD InVEstMent RePort: Transnational Corporations, agricultural Production and DEVELOPMENT (2009), available at http://unctad.org/en/docs/wir2009_en.pdf; Olivier De 
bought or leased for which we can establish both buyers and sellers; this figure jumps to over 200 million hectares if we consider all reported sales. ${ }^{86}$

What is of great concern here is the sharp change in the curve of acquisitions; it points to a break in a long-term trend, a break that might indicate a structural transformation in an old practice. The larger context within which this growth takes place is characterized by changes in the global economy and in financial markets, and, at a deeper level, changes in the larger interstate system, which is still the basic frame for cross-border transactions. Further, the financializing of commodities has brought new potentials for profit making to the primary sector, from food to minerals and metals, thus stimulating speculative investments in land.

Analytically, and in terms of the question organizing this essay, I see the facts of this sharp rise since 2006 as more significant to understanding the current period than the long-term trend towards acquiring foreign land. For example, in older imperial histories of land appropriation, as early as the $1960 \mathrm{~s}$, Japan was acquiring land in Asia and Brazil to grow food for its own consumption. The post-2006 acquisitions demonstrate a shift in the meaning and the modes of such land acquisitions.

One key difference with past imperial and colonial modes is that the world today is mostly, even if not completely, divided into putatively independent nation-states. ${ }^{87}$ Clearly, formal sovereignty can easily

Schutter, How Not to Think of Land Grabbing: Three Critiques of Large-Scale Investments in Farmland, 38 J. PEASANT STUD. 249 (2011), available at http://www.tandfonline.com/ doi/pdf/10.1080/03066150.2011.559008. For an online public database on land deals see Land Portal, LAND MATRIX, http://landportal.info/landmatrix (last visited Mar. 27, 2013).

86. See ANSEEUW ET AL., supra note 85; CotUlA, supra note 85; Land Portal, supra note 85. The Land Matrix database contains information about two types of data covering respectively acquisitions "reported" (200 million plus hectares) and "cross-checked." "Reported" data cover deals presented in published research reports and media reports and government registers where these are made public. "Cross-checked" data refer to those reported deals that are referenced from multiple sources; the cross-checking process involves an assessment of the reliability of the source of the information, triangulation with other information sources, and, if necessary, confirming with in-country partners in the networks of the Land Matrix partners. Media reports are not considered sufficient for cross-referencing. Research reports based on fieldwork, confirmation by known in-country partners, or official land records have been considered sufficient evidence. See What Methodology Does the Land Matrix Use?, Land Matrix, http://landportal.info/landmatrix/ get-the-detail\#pages-methodology (last visited Mar, 27, 2013).

87. States resisted at times, but it is worth noting what states succeeded in stopping foreign acquisitions. For instance, the United States did in the 1970s when it passed legislation preventing foreign investors aiming to buy land in the American midwest from doing so; at that time these were mostly from the Gulf states and Europe, who had up 
co-exist with coloniality, that is, post-historic colonialism. ${ }^{88}$ Yet, the aspirations of formal sovereignty help make visible the substantive assemblage of elements needed to execute some of these large scale acquisitions of land in a foreign country. It is no simple matter for a Swiss firm to buy land in Russia or for a Chinese government agency to acquire 2.8 million hectares of land in Zambia. Taking formal sovereignty on its terms allows me to trace the transformations that need to take place for these acquisitions and associated investments to be negotiated by foreign parties and a national government. It helps me recover the work of acquiring large amounts of land in a foreign country. Contractual arrangements are a basic element even when the two states have unequal power to impose their will or preferences. Of interest to the larger project on which this essay is based are the complex and indirect contractual arrangements through which some of these acquisitions are secured.

What is actually being measured in general descriptions of these acquisitions can vary considerably depending on the study. I have chosen the collectively generated data of the Land Matrix project in collaboration with International Land Coalition, ${ }^{89}$ which has made a major contribution to the subject. ${ }^{90}$ According to their definition the pertinent types of land acquisitions, all: (a) entail a transfer of rights to use, control, or own land through sale, lease, or concession; (b) imply a conversion from land used by smallholders, or for important environmental functions, to large-scale commercial use; (c) are 200 hectares or larger; and (d) were not concluded before the year 2000 when the FAO food price index was lowest. ${ }^{91}$

Land, broadly understood, has become one of the major new needs of advanced capitalism-for food and industrial crops, for underground water tables, and for traditional and new types of mining. I use the term "traditional economies" here to refer to smallholder economies, and

until then bought mostly firms, hotels, office buildings, Hollywood cinema studios, and more.

88. See e.g., Nelson Maldonado-Torres, On the Coloniality of Being: Contributions to the Development of a Concept, 21 CULTURAL STUD. 240 (2007); Walter D. Mignolo, Delinking: The Rhetoric of Modernity, the Logic of Coloniality and the Grammar of De-Coloniality, 21 CUlTURAL STUD. 449 (2007); Anibal Quijano, Coloniality and Modernity/Rationality, 21 CUlTURAL STUd. 168 (2007); Anibal Quijano, Coloniality of Power, Eurocentrism, and Latin America, 1 NEPANTLA: VIEWS FROM THE SOUTH 533 (2000).

89. See ANSEEUW, supra note 6; Land Portal, supra note 85.

90. It is important to note that acquisitions in OECD countries are generally not reflected in the data, as private transactions between one commercial user and another that do not involve a conversion of tenure system or away from smallholder production are not included in the Land Matrix. It is of course the case that this definition of land acquisitions would not be the most common in Europe.

91. See ANSEEUW ET AL., supra note 85, at vi. 
generally the absence of financialized commodification and of corporatization. Thus, I do not include hundred years old plantations, even though they are old. Clearly these definitions of "traditional" economies are approximations to complex and mixed realities, subjects I addressed in earlier work, ${ }^{92}$ and also more recently. ${ }^{93}$ At a time of extreme financialization and systemic transformation, the growing demand for those material resources has ascended in importance and visibility, and has stimulated their financializing.

The demand for resources, and what it takes to fulfill it, is part of the systemic deepening of the current phase of capitalism. It comes down to an expansion of the operational space for advanced capitalism through the expulsion of people from a range of institutional settings in both the Global South and North, with specific modalities in each. ${ }^{94}$ The sharp increases in displaced peoples, poverty, and illnesses that kill even though curable are part of this new phase; they are not anomalies. Likewise, widespread hunger and starvation are not anomalies, even though there is plenty of food produced. Nor are these types of juxtapositions new. They have happened in other phases of the development of capitalist economies.

At this vast a scale, land acquisitions can transform sovereign national territory into a far more elementary condition-land for usufruct. The latter is not only a more elementary condition than territory, but also is more univocal. Where territory contains logics for claim-making (i.e. citizenship), land for usufruct by large foreign owners would seem to go in a different direction. One way of conceiving of this shift is as a partial and specialized reassembling of bits and pieces of territory, authority, and rights once ensconced in the sovereign nation-state. These have now become a stretch of land owned by a foreign firm or government and have begun to shift towards a novel formation. This is also an instance of what I refer to as the endogenizing of the global into the national-in this case, a very material and visible one.

\section{CONCLUSION}

The central focus in this article was on disassemblings taking place inside sovereign state territory and authority. It was not concerned with the more common subject of the deregulation of interstate borders.

92. See, e.g., Saskia Sassen, The Mobility of Labor and Capital: A Study IN INTERNATIONAL INVESTMENT AND LABOR FLOW (1988).

93. Saskia Sassen, A Savage Sorting of Winners and Losers: Contemporary Versions of Primitive Accumulation, 7 GLOBALIZATIONS 23 (2010).

94. SASSEN, supra note 7. 
I used a variety of instances that capture this disassembling. Some consist of formally organized practices, such as the spread of contractual governance that replaces regulations that were in the public domain; this switch covers fields as diverse as business and immigration. Once these shifts to private contractual modes of governance have taken place, they render invisible the shift itself and the original governmental regulations they replace. Theoretically speaking, they become naturalized: lost is the fact that they were once components of state sovereignty. The cognoscenti and those tracking these evolutions know, but the public domain and the public conversation easily loses track and engages what is given in the present.

Others consist of a misuse of formal instruments in order to avoid binding law. Here I examined how states increasingly use the high seas to stop refugees and avoid non-refoulement rules. These developments can be conceived of as the making of new types of jurisdictions that have variable relations to the traditional jurisdiction of the state over its territory. They contribute to an emergent misalignment between territory and territoriality. And this misalignment can keep growing even if interstate borders do not change at all.

A different vector is the making of structural holes in the tissue of national sovereign territory. Here the cases used were large-scale land acquisitions by foreign governments and firms, and the United States' establishment of military bases in a large number of foreign countries. These and other such developments entail new types of borderings and informal jurisdictions that are taking shape inside national territory.

Both sets of developments can coexist comfortably with the existing regime of interstate borders. I argue that the excessive focus on borders and their deregulation easily leads to an overlooking of the transformations happening inside national sovereign territory.

The development of contractual modes that replace governmental regulations, the making of informal jurisdictions inside sovereign territory, and the misuse of formal jurisdictions to avoid a particular binding law, all have an additional outcome. They can render invisible original aims and intentions, alter the valence of existing law, and produce novel informal systemic capabilities. The focus here was on normatively dubious developments, including both the strengthening of private orderings where a higher norm would be desirable, and the states' contractualizing of practices that should remain in the public domain and under public oversight. But in itself, some of these shifts need not be negative, even though the focus here was on negative instances. I rather see the possibility of multi-valence, some positive and some not so. Thus, re-coding what were once national norms as elements of global 'normative' orderings can enhance global capitalism, 
but it can also enhance the global commons, from human rights to the environment. But in both instances we need to render visible these developments and their origins. 
